\title{
USO DO HIPOCLORITO DE SÓDIO PARA DEGRADAÇÃO DO ENDOCARPO DE SEMENTES DE CAFEEIRO COM DIFERENTES GRAUS DE UMIDADE ${ }^{1}$
}

\author{
VALDINEI SOFIATTI ${ }^{2}$, EDUARDO FONTES ARAUJO ${ }^{3}$, ROBERTO FONTES ARAUJO ${ }^{4}$, MÚCIO SILVA \\ REIS $^{3}$, LEDA VERONICA BENEVIDES DANTAS SILVA ${ }^{5}$, ADELIANO CARGNIN ${ }^{6}$
}

\begin{abstract}
RESUMO - Objetivou-se estudar combinações entre concentrações de hipoclorito de sódio e tempos de pré-embebição que proporcionem maior velocidade de germinação das sementes de cafeeiro com graus de umidade entre 13 e $33 \%$ em base úmida. As sementes da variedade Catuaí Vermelho IAC 44 foram secadas à sombra até atingirem as umidades desejadas. Foram realizados cinco ensaios, um para cada grau de umidade das sementes $(13,18,23,28$ e 33\%). Cada ensaio foi constituído por 12 tratamentos, formados pelas combinações de 5 concentrações de hipoclorito de sódio na solução de pré-embebição (3, 4, 5, 6 e 7\% de cloro ativo) e 2 tempos de pré-embebição (3 e 6 horas), além de sementes com pergaminho e sem pergaminho, removido manualmente (testemunha). As sementes foram avaliadas por meio dos testes de primeira contagem de germinação, germinação, índice de velocidade de germinação e classificação do vigor das plântulas. Os resultados mostraram que a pré-embebição das sementes de cafeeiro em hipoclorito de sódio na concentração de $6 \%$ de cloro ativo, durante 3 horas, além de degradar o pergaminho eficientemente, proporcionou germinação e índice de velocidade de germinação semelhantes ao tratamento testemunha, quando as sementes apresentavam grau de umidade inicial entre 23 e $33 \%$. Nas sementes com grau de umidade de 18 e $13 \%$, a pré-embebição em hipoclorito de sódio proporcionou desempenho germinativo inferior às sementes sem pergaminho, removido manualmente, independente da combinação entre concentração e tempo de embebição utilizada.
\end{abstract}

Termos para indexação: hipoclorito de sódio, degradação do pergaminho, sementes, cafeeiro.

\section{USE OF SODIUM HYPOCHLORITE TO DEGRADE THE ENDOCARP IN COFFEE SEEDS AT DIFFERENT MOISTURE CONTENTS}

\begin{abstract}
The objective of this study was to evaluate the combinations between sodium hypochlorite concentrations and presoaking times that would provide higher germination of coffee seeds with moisture contents from 13 to $33 \%$ (w.b.). The seeds of Catuaí Vermelho IAC 44 variety were dried in the shade until they reached the desired moisture contents. Five assays were accomplished, one for each moisture content of the seeds (13, 18, 23, 28 and 33\%). Each assay consisted of 12 treatments, each one consisting of combinations of five sodium hypochlorite concentrations $(3,4,5$, 6 and $7 \%$ active chlorine) in the presoaking solution and two presoaking times ( 3 and $6 \mathrm{hr}$ ), besides the seeds with or without endocarp that were manually removed (control). The seeds were evaluated,
\end{abstract}

\footnotetext{
${ }^{1}$ Submetido em 17/04/2007. Aceito para publicação em 20/01/2008. Parte da Tese de Doutorado do primeiro autor apresentada a Universidade Federal de Viçosa (UFV).

${ }^{2}$ Eng. Agro., DS., Pesquisador Embrapa Algodão, Rua Osvaldo Cruz 1143, Bairro Centenário, CP 174, CEP 58107-720, Campina Grande-PB. E-mail: vsofiatti@cnpa.embrapa.br

${ }^{3}$ Eng. Agr ${ }^{\circ}$., DS., Professor Adjunto, Departamento de Fitotecnia, Universidade Federal de Viçosa (UFV). E-mail: efaraujo@ufv.br; msreis@ufv.br
}

${ }^{4}$ Eng. Agr ${ }^{\circ}$., DS., Pesquisador, Centro Tecnológico da Zona da Mata (CTZM), Empresa de Pesquisa Agropecuária de Minas Gerais (EPAMIG). E-mail: rfaraujo@ufv.br

${ }^{5}$ Eng. Agr ${ }^{\circ}$, Departamento de Fitotecnia, Universidade Federal de Viçosa E-mail: ledavdantas@gmail.com.

${ }^{6}$ Eng. Agr ${ }^{\circ}$., DS., Pesquisador Embrapa Cerrados, BR 020 Km 18. Planaltina, DF - Brasil - CEP 73310-970. E-mail: adeliano.cargnin@cpac.embrapa.br. 
by using the following tests: first germination counting, germination, germination speed index and seedling vigor. According to the results, the presoaking of the coffee seeds into sodium hypochlorite at $6 \%$ concentration active chlorine for three hours promoted an efficient degradation of the endocarp, besides providing germination speed index similar to the control, when seeds showed initial moisture content between 23 and 33\%. In those seeds with moisture content at 18 and 13\%, the presoaking in sodium hypochlorite led to an inferior germination performance of the seeds relative to the seeds without endocarp that was manually removed, regardless of the combination between concentration and the presoaking time.

Index terms: sodium hypochlorite, endocarp degradation, seeds, coffee.

\section{INTRODUÇÃO}

Nos últimos anos, novas tecnologias e métodos de cultivo, como o plantio em espaçamentos menores, introdução de cultivares melhorados e avanços no manejo de pragas e doenças, vêm sendo disponibilizados aos produtores de café, possibilitando aumentos significativos na produtividade da cultura. No entanto, a germinação das sementes de maneira lenta e desuniforme ainda constitui grande empecilho à produção de mudas de qualidade, causando dificuldades à instalação da cultura no campo (Sguarezi et al., 2001).

Existem diversas hipóteses sobre as causas dos problemas na germinação, sendo a presença do pergaminho na semente a mais provável (Valio, 1980; Guimarães et al., 1998; Carvalho et al., 1999). Entretanto, a pesquisa ainda não conseguiu esclarecer todos os mecanismos que trazem tais prejuízos ao processo germinativo.

De acordo com Valio (1980), a inibição da germinação das sementes de cafeeiro pelo pergaminho não é devido à impermeabilidade à água ou a gases, nem à presença de substâncias inibidoras, mas, provavelmente, causada por impedimento mecânico ao crescimento do embrião. Por outro lado, Silva et al. (2004) sugerem que o ácido abscísico (ABA) exerce influência sobre a velocidade de germinação das sementes de cafeeiro controlando tanto o potencial de crescimento do embrião quanto a segunda fase da germinação em que ocorre enfraquecimento do endosperma pela inibição de duas isoformas da enzima endo- $\beta$-mannanase.

A retirada do pergaminho é uma prática eficiente para aceleração do processo germinativo de sementes de cafeeiro (Guimarães et al., 1998). Araujo et al. (2004) relatam que a remoção desta estrutura deve ser realizada cuidadosamente, uma vez que o embrião está localizado em camada superficial da semente. Esses autores observaram que a remoção manual foi o método mais eficaz para o aumento na porcentagem e aceleração da germinação, sem causar danos às sementes. Contudo, a remoção manual do pergaminho é um procedimento bastante trabalhoso, pois requer o manuseio individual das sementes, acarretando aumento no custo de produção das mudas. Trabalhos realizados por Meireles (2004) mostraram que a pré-embebição das sementes de cafeeiro em solução aquosa de hipoclorito de sódio, contendo $5,0 \%$ de cloro ativo, durante um período de 6 horas, foi eficiente na degradação do pergaminho sem causar danos ao embrião, proporcionando percentagem e velocidade de germinação semelhantes à remoção manual do pergaminho. Entretanto, esses estudos foram realizados com sementes apresentando teor de água em torno de $28 \%$, não sendo realizados testes com outros graus de umidade das sementes.

As sementes de cafeeiro apresentam comportamento bastante distinto das demais espécies, principalmente no que se refere à tolerância à dessecação. Por esta razão, foi proposta uma classificação para as sementes quanto à capacidade de tolerância à dessecação. As sementes do cafeeiro foram, inicialmente, enquadradas no grupo das recalcitrantes, embora estudos realizados por Bacchi (1955, $1956,1958)$ indicarem que essas sementes poderiam ser secadas até $10 \%$ de umidade, sem causar danos à qualidade fisiológica. Ellis et al. (1990), trabalhando com sementes de cafeeiro, incluíram a categoria intermediária na classificação de Roberts (1973). Assim, passou a ser aceita a classificação que admite as sementes "ortodoxas" (toleram dessecação até graus de umidade próximos a 5\%), "intermediárias" (toleram dessecação até graus de umidade em torno de 10$12,5 \%$ e têm a viabilidade reduzida em umidades inferiores) e "recalcitrantes" (perdem a viabilidade quando dessecadas até graus de umidade abaixo de 15-20\%).

As sementes de cafeeiro, mesmo apresentando curta longevidade (Gentil, 2001), podem ser armazenadas, comercializadas e semeadas numa faixa de graus de umidade variando entre 10 (Bacchi, 1955, 1956, 1958) e 48\% (Araujo, 1988). Conforme comentado anteriormente, Meireles (2004) trabalhou com hipoclorito de sódio em sementes com grau 
de umidade de $28 \%$. Entretanto, o tempo de exposição e a concentração de hipoclorito de sódio, necessários para degradação do pergaminho sem causar danos ao embrião, podem ser influenciados pelo grau de umidade inicial das sementes.

O objetivo do presente trabalho foi estudar combinações entre concentrações de hipoclorito de sódio e tempos de pré-embebição que proporcionem maior velocidade de germinação das sementes de cafeeiro, com graus de umidade entre 13 e $33 \%$ em base úmida.

\section{MATERIAL E MÉTODOS}

O experimento foi conduzido no Laboratório de Pesquisa em Sementes do Departamento de Fitotecnia da Universidade Federal de Viçosa (UFV), em Viçosa-MG. Foram utilizadas sementes de café arábica (Coffea arabica L.), cultivar Catuaí Vermelho IAC 44, colhidas manualmente no estádio cereja, as quais foram submetidas ao despolpamento e fermentação. No beneficiamento as sementes foram submetidas a limpeza para retirada das sementes partidas e de materiais mais leves por meio de uma máquina de ventilador e peneiras. A retirada das sementes chochas foi feita pela passagem das sementes em mesa de gravidade. Após o beneficiamento as sementes foram acondicionadas em embalagem impermeável, permanecendo armazenadas durante aproximadamente três meses em temperatura de $20 \pm 2^{\circ} \mathrm{C}$. Após esse período, as sementes apresentavam grau de umidade inicial de $40 \%$ e, foram secadas à sombra com temperatura e umidade relativa ambiente, sendo para isso dispostas em sacos de filó, tamanho 10 x $15 \mathrm{~cm}$, contendo aproximadamente $1,3 \mathrm{~kg}$ de sementes cada embalagem, até atingirem os graus de umidade de $13 \pm 1$, $18 \pm 1,23 \pm 1,28 \pm 1$ e $33 \pm 1 \%$ em base úmida.

Foram realizados cinco ensaios, um para cada grau de umidade das sementes. Em cada ensaio, as sementes foram submetidas aos tratamentos de pré-embebição em solução aquosa contendo hipoclorito de sódio nas concentrações de 3, 4, 5, 6 e 7\% de cloro ativo, durante um período de 3 e 6 horas. Além destes tratamentos, para cada grau de umidade, foi acrescentado um tratamento constituído de sementes intactas com pergaminho e um tratamento testemunha constituído por sementes cujo pergaminho foi removido manualmente, a fim de evitar danos ao embrião. A concentração de cloro ativo do hipoclorito de sódio foi determinada no Laboratório de Química Analítica (LAQUA) do Departamento de Química da UFV. A concentração de cloro ativo da solução de pré-embebição foi obtida por meio da diluição do hipoclorito de sódio comercial com água destilada.
Para os tratamentos pré-germinativos, as sementes foram acondicionadas em caixas gerbox, onde ficaram pré-embebidas em solução de hipoclorito de sódio, de acordo com os tratamentos, adotando-se a proporção de $120 \mathrm{~mL}$ de solução de hipoclorito de sódio para 240 sementes ou volume correspondente. Para que não flutuassem, utilizouse o telado das caixas gerbox sobre as sementes, para que ficassem imersas. Após esse procedimento, as caixas gerbox foram tampadas e levadas para uma BOD com temperatura constante de $25^{\circ} \mathrm{C}$ na ausência de luz, onde permaneceram durante os períodos referentes a cada tratamento (3 e 6 horas). Decorridos os tempos de exposição das sementes à solução aquosa contendo hipoclorito de sódio, as mesmas foram lavadas em água corrente, durante 90 segundos.

Para avaliar a atuação da solução aquosa, contendo hipoclorito de sódio, sobre as sementes, foi determinado o pH da solução em intervalos de uma hora, utilizando-se pHmetro digital, marca DIGIMED, modelo DM-2. Também foi determinada a temperatura da solução a cada 30 minutos, utilizando-se termômetro analógico. Os resultados de $\mathrm{pH}$ foram expressos em unidades de $\mathrm{pH}$ e a temperatura em graus centígrados $\left({ }^{\circ} \mathrm{C}\right)$.

As sementes de cada tratamento foram submetidas aos testes a seguir. 1) Grau de umidade - foi determinado antes e após o período de pré-embebição das sementes. O pergaminho foi removido manualmente, antes da determinação, devido ao acúmulo de água entre o mesmo e o endosperma mascarar a real umidade das sementes. Após a remoção do pergaminho, as sementes foram secadas externamente sobre papel toalha, para remoção da umidade superficial. O grau de umidade foi determinado por meio do método da estufa a $105 \pm 3^{\circ} \mathrm{C}$, durante um período de 24 horas, utilizando-se 3 repetições para cada tratamento (Brasil, 1992). 2) Teste de germinação (TG) - conduzido com 200 sementes, utilizando como substrato, rolos de papel germitest, previamente umedecidos com água destilada na quantidade de 2,5 vezes a sua massa inicial. Os rolos foram mantidos em germinador à temperatura de $30^{\circ} \mathrm{C}$, durante um período de 30 dias na ausência de luz, conforme as Regras para Análise de Sementes (Brasil, 1992). Os resultados foram expressos em percentagem de plântulas normais. 3) Primeira contagem de germinação (PCG) - as sementes que apresentavam protrusão da raiz primária na primeira contagem do teste de germinação, realizada no $15^{\circ}$ dia após a semeadura, foram consideradas germinadas. 4) Índice de velocidade de germinação (IVG) - realizado em conjunto com o teste de germinação, sendo as avaliações realizadas a cada 4 dias, a partir do dia em que as primeiras sementes emitiram radícula até o dia da última contagem 
estabelecida pelas Regras para Análise de Sementes (Brasil, 1992). Para o cálculo, foi utilizada a fórmula proposta por Maguirre (1962). 5) Classificação do vigor das plântulas - ao término do teste de germinação, as plântulas normais foram avaliadas de acordo com o vigor, sendo classificadas como plântulas normais fortes, quando apresentavam todas as estruturas essenciais, sistema radicular bem desenvolvido e comprimento da parte aérea superior a $1,0 \mathrm{~cm}$. Os resultados foram expressos em percentagem de plântulas normais fortes.

Os ensaios foram instalados em delineamento inteiramente casualizado com quatro repetições. Os dados experimentais foram submetidos à análise de variância. Para cada grau de umidade das sementes, os tratamentos obtidos pelas combinações das concentrações de hipoclorito de sódio e tempos de pré-embebição, além do tratamento sementes com pergaminho, foram comparados ao tratamento testemunha (sementes sem pergaminho, removido manualmente), aplicando-se o teste de Dunnett unilateral à esquerda com $5 \%$ de probabilidade e, dessa forma, identificando-se os tratamentos que apresentaram resultados inferiores ao tratamento testemunha.

\section{RESULTADOS E DISCUSSÃO}

$\mathrm{O}$ pH inicial da solução aquosa, contendo hipoclorito de sódio, foi de aproximadamente 12,8, independentemente da concentração utilizada (Tabela 1). Desta forma, verificou-se que o hipoclorito de sódio possui elevada capacidade de tamponamento, não alterando o pH da solução com as diferentes diluições para obtenção das concentrações utilizadas no experimento. O cloro é parcialmente solúvel em meio aquoso, se apresentando nas formas de cloro molecular $\left(\mathrm{Cl}_{2}\right)$ e ácido hipocloroso $(\mathrm{HOCl})$, sendo que o $\mathrm{pH}$ é o principal fator que atua no controle da forma como o cloro se apresenta na solução. Em pH elevado, as formas predominantes são o ácido hipocloroso e o íon hipoclorito (Hise, 1996). Assim, verifica-se que o cloro encontra-se na solução aquosa de pré-embebição, predominantemente, nas formas de ácido hipocloroso e íon hipoclorito.

$\mathrm{OpH}$ da solução não foi influenciado pelo grau de umidade das sementes, sendo influenciado apenas pela concentração de hipoclorito de sódio na solução durante o período de pré-embebição. $\mathrm{O}$ valor de $\mathrm{pH}$ da solução decresceu de forma quadrática até o final do período de embebição (Tabela 1). $\mathrm{O}$ decréscimo no valor de $\mathrm{pH}$ (aumento da concentração de hidrogênio) ocorreu de maneira mais acentuada nas maiores concentrações de hipoclorito de sódio da solução de pré-embebição das sementes. A atuação do hipoclorito de sódio sobre o pergaminho das sementes de cafeeiro é ainda desconhecida; entretanto, compostos químicos à base de cloro são utilizados na indústria da celulose para degradação da lignina (Dence, 1996). Como o pergaminho das sementes de cafeeiro apresenta elevados teores de lignina (Elías, 1978), provavelmente a atuação do hipoclorito de sódio ocorra na degradação da lignina da parede celular de suas células. As reações que ocorrem são de oxidação, substituição ou adição de cloro no anel aromático presente na molécula de lignina (Hise, 1996). O decréscimo mais acentuado nos valores de pH da solução aquosa de hipoclorito de sódio dos tratamentos com concentração mais elevada de cloro ativo (Tabela 1) ocorreu, provavelmente, devido a degradação da lignina acontecer mais rapidamente em relação aos tratamentos com menores concentrações de hipoclorito de sódio, liberando mais íons hidrogênio para a solução.

A temperatura da solução não foi afetada pelo grau de umidade das sementes, porém a variação na concentração de hipoclorito de sódio ocasionou alteração na temperatura, durante o período de pré-embebição, conforme apresentado na Tabela 2 .

A solução de pré-embebição das sementes atingiu a temperatura de $25^{\circ} \mathrm{C} \mathrm{em}$, aproximadamente, uma hora

TABELA 1. Efeito da concentração (C) de cloro ativo na solução de pré-embebição sobre o pH, durante o período de pré-embebição dos sementes de cafeeiro

\begin{tabular}{cccccccccc}
\hline \multirow{2}{*}{ C (\%) } & \multicolumn{7}{c}{ Período de pré-embebição (horas) } & Equação ajustada & \multirow{2}{*}{$\mathrm{R}^{2}$} \\
\cline { 2 - 6 } & 0 & 1 & 2 & 3 & 4 & 5 & 6 & & \\
\hline 3 & 12,7 & 11,6 & 9,3 & 8,7 & 8,5 & 8,3 & 8,1 & $\hat{\mathrm{Y}}=12,79-1,87 \mathrm{x}+0,19 \mathrm{x}^{2}$ & 0,97 \\
4 & 12,8 & 12,0 & 9,1 & 8,6 & 8,0 & 7,6 & 7,3 & $\hat{\mathrm{Y}}=13,04-2,09 \mathrm{x}+0,18 \mathrm{x}^{2}$ & 0,96 \\
5 & 12,8 & 12,1 & 9,3 & 8,2 & 7,0 & 6,8 & 6,7 & $\hat{\mathrm{Y}}=13,26-2,24 \mathrm{x}+0,19 \mathrm{x}^{2}$ & 0,97 \\
6 & 12,8 & 12,1 & 8,8 & 6,5 & 6,4 & 6,6 & 6,7 & $\hat{\mathrm{Y}}=13,46-2,96 \mathrm{x}+0,30 \mathrm{x}^{2}$ & 0,94 \\
7 & 12,7 & 12,2 & 8,3 & 6,2 & 6,4 & 6,6 & 6,8 & $\hat{\mathrm{Y}}=13,50-3,18 \mathrm{x}+0,30 \mathrm{x}^{2}$ & 0,92 \\
\hline
\end{tabular}


TABELA 2. Temperatura $\left({ }^{\circ} \mathrm{C}\right)$ da solução aquosa, durante o período de pré-embebição das sementes de cafeeiro, de acordo com a concentração de cloro ativo $(C)$

\begin{tabular}{ccccccccccccccc}
\hline \multirow{2}{*}{ C (\%) } & \multicolumn{10}{c}{ Período de pré-embebição (horas) } \\
\cline { 2 - 13 }$y$ & 0 & 0,5 & 1,0 & 1,5 & 2,0 & 2,5 & 3,0 & 3,5 & 4,0 & 4,5 & 5,0 & 5,5 & 6,0 \\
\hline 3 & 19 & 22 & 24,5 & 26 & 25 & 25,8 & 26 & 25 & 25 & 25 & 25 & 25 & 25 \\
4 & 19 & 22 & 24,5 & 26 & 26 & 27 & 27 & 26,5 & 26,5 & 26,5 & 26 & 25,5 & 25 \\
5 & 19 & 22 & 24,5 & 26 & 27 & 28,5 & 29,2 & 29 & 28 & 27 & 26 & 25 & 25 \\
6 & 19 & 22 & 24,5 & 28 & 29 & 32,5 & 32 & 28 & 26 & 25,5 & 25 & 25 & 25 \\
7 & 19 & 22 & 25,0 & 28 & 32 & 37 & 32 & 28 & 25 & 25 & 25 & 25 & 25 \\
\hline
\end{tabular}

* Temperatura da $\mathrm{BOD} \pm 25^{\circ} \mathrm{C}$.

após o acondicionamento na câmara BOD. No tratamento com concentração de $3 \%$ de cloro ativo, após a solução de pré-embebição ter atingido a temperatura de $25^{\circ} \mathrm{C}$, não houve alteração na temperatura. Nos tratamentos com concentrações superiores a $3 \%$ de cloro ativo, após terem atingido a temperatura da BOD (após aproximadamente 1,5 horas) a temperatura da solução começou a aumentar. Quanto maior a concentração de hipoclorito de sódio, maior foi o aumento na temperatura da solução, atingindo $37^{\circ} \mathrm{C}$ na concentração de $7 \%$ de cloro ativo, após 2,5 horas de pré-embebição (Tabela 2). O aumento na temperatura da solução de hipoclorito de sódio, em relação à temperatura do ambiente $\left(25^{\circ} \mathrm{C}\right)$, indica que as reações para degradação do pergaminho das sementes são exotérmicas. As reações do hipoclorito de sódio com o pergaminho das sementes ocorrem mais rapidamente em concentrações mais elevadas de hipoclorito de sódio, o que pode ser observado pelo menor período que a solução permaneceu com temperatura acima do ambiente, à medida que a concentração de hipoclorito de sódio foi aumentada. $\mathrm{Na}$ concentração de $7 \%$ de cloro ativo, após 4 horas de pré-embebição, a temperatura foi reduzida para $25^{\circ} \mathrm{C}$ (temperatura do ambiente), enquanto, nas concentrações de 4, 5 e $6 \%$, os tempos necessários para atingirem a temperatura ambiental foram de 6, 5,5 e 5 horas, respectivamente.

As sementes com grau de umidade inicial de 13 e $18 \%$ tiveram sua umidade aumentada até valores superiores a $22 \mathrm{e}$ $27 \%$, respectivamente, em apenas 3 horas de pré-embebição (Tabela 3). Nos tratamentos com concentrações de 6 e $7 \%$ de cloro ativo, as sementes atingiram maior grau de umidade devido, provavelmente, a reação do hipoclorito de sódio ter ocasionado aumento na temperatura da solução de pré-embebição (Tabela 2), favorecendo o aumento do grau de umidade. Meireles (2004) também verificou que as sementes submetidas à pré-embebição em solução aquosa, contendo hipoclorito de sódio, absorvem maiores quantidades de solução em concentrações de cloro ativo superiores a 5\%.

TABELA 3. Grau de umidade de sementes de cafeeiro, após os tratamentos pré-germinativos, durante períodos de 3 e 6 horas, em sementes com diferentes graus de umidade inicial

\begin{tabular}{ccccccc}
\hline \multirow{2}{*}{ C (\%) } & \multirow{2}{*}{ Tempo (h) } & \multicolumn{5}{c}{ Grau de umidade inicial das sementes (\% b.u.) } \\
\cline { 2 - 7 } & 3 & 13 & 18 & 23 & 28 & 33 \\
\hline \multirow{2}{*}{3} & 6 & $22,2 \pm 0,5^{*}$ & $27,1 \pm 1,3$ & $27,2 \pm 0,8$ & $31,3 \pm 0,5$ & $36,5 \pm 0,6$ \\
& 3 & $25,8 \pm 1,1$ & $29,1 \pm 0,1$ & $28,3 \pm 0,1$ & $33,1 \pm 0,3$ & $37,3 \pm 0,3$ \\
\hline \multirow{2}{*}{4} & 6 & $23,1 \pm 1,0$ & $27,7 \pm 1,0$ & $27,1 \pm 0,3$ & $31,6 \pm 1,0$ & $37,0 \pm 0,3$ \\
& 3 & $23,0 \pm 0,3$ & $29,7 \pm 0,2$ & $28,8 \pm 0,3$ & $33,6 \pm 0,5$ & $37,9 \pm 0,2$ \\
\hline \multirow{2}{*}{5} & 6 & $26,9 \pm 0,2$ & $29,0 \pm 0,1$ & $29,1 \pm 0,4$ & $33,4 \pm 0,3$ & $37,8 \pm 0,2$ \\
\hline \multirow{2}{*}{6} & 3 & $26,8 \pm 0,1$ & $29,8 \pm 0,2$ & $28,3 \pm 0,2$ & $32,3 \pm 0,2$ & $36,8 \pm 0,2$ \\
& 6 & $28,9 \pm 0,9$ & $31,2 \pm 1,2$ & $29,0 \pm 0,3$ & $33,5 \pm 0,7$ & $37,2 \pm 0,1$ \\
\hline \multirow{2}{*}{7} & 3 & $28,8 \pm 0,8$ & $31,4 \pm 0,2$ & $30,0 \pm 0,6$ & $32,6 \pm 0,1$ & $36,7 \pm 0,2$ \\
& 6 & $29,8 \pm 0,2$ & $31,6 \pm 1,2$ & $30,6 \pm 0,2$ & $33,5 \pm 0,8$ & $36,8 \pm 0,1$ \\
\hline
\end{tabular}

*Média \pm desvio padrão. 
O aumento no grau de umidade das sementes, durante o período de pré-embebição, foi menor à medida que o grau de umidade inicial das sementes aumentou (Tabela 3 ). Isto evidencia que, quanto menor o grau de umidade inicial das sementes, maior é a absorção da solução de hipoclorito de sódio. Provavelmente, quando as sementes apresentam baixo grau de umidade, a absorção da solução é mais rápida, o que ocasiona danificações nas células, reduzindo a capacidade seletiva das membranas, favorecendo ainda mais a absorção de solução contendo hipoclorito de sódio.

A percentagem de germinação das sementes sem pergaminho, removido manualmente (testemunha), superou $90 \%$, exceto nas sementes com grau de umidade de $13 \%$, onde a germinação foi de 79\% (Tabela 4). As sementes com pergaminho apresentaram baixa percentagem de germinação em todos os graus de umidade. Araujo et al. (2004) também verificaram que a remoção manual do pergaminho é eficiente em promover a germinação e aumentar a velocidade de germinação das sementes de cafeeiro. A secagem de sementes até $13 \%$ de umidade prejudicou sua germinação. Dessa forma, as sementes de cafeeiro tiveram maior poder germinativo, quando apresentavam maior grau de umidade. Apesar de serem encontrados, na literatura, resultados contrastantes quanto ao teor de água adequado para a conservação de sementes de cafeeiro (Gentil, 2001), alguns trabalhos evidenciam melhor desempenho de sementes armazenadas com alto grau de umidade (Silva e Dias, 1985).

A percentagem de germinação das sementes, em que o pergaminho não foi removido, foi muito baixa em todos os graus de umidade das sementes. Baixas percentagens de germinação das sementes compergaminhosão freqüentemente relatadas na literatura (Valio, 1976; Guimarães et al., 1998; Carvalho et al., 1999; Araujo et al., 2004). O aumento na percentagem de germinação com a remoção do pergaminho pode estar relacionado com a presença de substâncias inibidoras da germinação no pergaminho (Rena e Maestri, 1986) ou com o impedimento físico ao crescimento do embrião (Valio, 1980).

A pré-embebição das sementes em solução aquosa contendo hipoclorito de sódio foi eficiente na degradação do pergaminho das sementes e promoção da germinação, apenas quando o grau de umidade inicial das sementes era igual ou superior a $23 \%$, conforme apresentado na Tabela 4. Em sementes com grau de umidade de $23 \%$, a pré-embebição com hipoclorito de sódio na concentração de $6 \%$ de cloro ativo, durante 3 horas, foi o único tratamento que proporcionou germinação das sementes semelhante àquela obtida com a remoção manual do pergaminho. Quando as sementes apresentavam 28\% de umidade, a utilização de hipoclorito de sódio nas concentrações de 4, 5 e

TABELA 4. Germinação (\%) de sementes de cafeeiro, de acordo com o tratamento para degradação do pergaminho de sementes com diferentes graus de umidade inicial

\begin{tabular}{|c|c|c|c|c|c|c|}
\hline \multicolumn{2}{|c|}{ Tratamento } & \multicolumn{5}{|c|}{ Grau de umidade inicial das sementes (\% b.u.) } \\
\hline Cloro ativo (\%) & Tempo (h) & 13 & 18 & 23 & 28 & 33 \\
\hline \multirow{2}{*}{3} & 3 & 40 & 24 & 11 & 43 & 11 \\
\hline & 6 & 11 & 62 & 78 & 72 & 67 \\
\hline \multirow{2}{*}{4} & 3 & 50 & 68 & 41 & $91 *$ & 53 \\
\hline & 6 & 6 & 50 & 63 & 15 & 66 \\
\hline \multirow{2}{*}{5} & 3 & 19 & 82 & 74 & $91^{*}$ & 82 \\
\hline & 6 & 0 & 30 & 32 & 7 & 35 \\
\hline \multirow{2}{*}{6} & 3 & 8 & 55 & $93^{*}$ & $94 *$ & $89 *$ \\
\hline & 6 & 0 & 21 & 11 & 0 & 17 \\
\hline \multirow{2}{*}{7} & 3 & 0 & 17 & 76 & 22 & 75 \\
\hline & 6 & 0 & 12 & 10 & 0 & 5 \\
\hline \multicolumn{2}{|c|}{$\begin{array}{l}\text { Sementes sem tratamento (com } \\
\text { pergaminho) }\end{array}$} & 2 & 20 & 19 & 32 & 12 \\
\hline \multicolumn{2}{|c|}{$\begin{array}{l}\text { Testemunha (sem pergaminho, } \\
\text { remoção manual) }\end{array}$} & 79 & 93 & 93 & 92 & 93 \\
\hline \multicolumn{2}{|l|}{ CV $(\%)$} & 22,7 & 9,6 & 9,9 & 9,2 & 9,3 \\
\hline
\end{tabular}

*Médias iguais ao tratamento testemunha pelo teste de Dunnett a $5 \%$ de probabilidade, na mesma coluna. 
$6 \%$ de cloro ativo, durante um período de 3 horas, promoveu germinação de forma semelhante à remoção manual do pergaminho. Nas sementes apresentando grau de umidade de $33 \%$, a concentração de $6 \%$ de cloro ativo na solução de pré-embebição, durante 3 horas, foi o único tratamento em que a percentagem de germinação não diferiu daquela obtida com a remoção manual do pergaminho.

De acordo com os resultados obtidos no teste de germinação, verifica-se que o grau de umidade das sementes de $28 \%$ permite a utilização de uma faixa mais ampla de concentrações de hipoclorito de sódio para a degradação do pergaminho. O aumento no grau de umidade das sementes para $33 \%$, ou a redução para $23 \%$, faz com que uma pequena variação na concentração de hipoclorito de sódio afete negativamente a germinação dessas sementes.

Estudos realizados por Meireles (2004), utilizando sementes com grau de umidade de $28 \%$, mostraram que a pré-embebição em hipoclorito de sódio com $5 \%$ de cloro ativo, durante um período de 6 horas, foi eficiente na degradação do pergaminho, sem causar danos às sementes, de forma semelhante aos resultados obtidos no presente trabalho. Entretanto, no presente trabalho, o período de pré-embebição de 6 horas ocasionou danos às sementes, reduzindo sua percentagem de germinação. Vale ressaltar que Meireles (2004) não testou o tempo de pré-embebição de 3 horas, bem como as sementes utilizadas por esse autor estavam no início do período de armazenamento. No presente trabalho, as sementes foram armazenadas durante três meses, antes da realização do experimento. Assim, o vigor pode ter sido afetado negativamente durante o armazenamento, prejudicando o vigor das sementes e reduzindo a sua capacidade em tolerar o hipoclorito de sódio durante um maior período de exposição. De qualquer forma, o período de pré-embebição de 3 horas apresenta vantagem, em relação ao período de 6 horas, pois reduz o tempo de tratamento antes da semeadura.

Em sementes com 18\% de umidade, a pré-embebição das sementes com hipoclorito de sódio proporcionou germinação das sementes inferior à remoção manual do pergaminho (Tabela 4). Entretanto, a pré-embebição com hipoclorito de sódio com $5 \%$ de cloro ativo, durante um período de três horas, proporcionou germinação superior a $80 \%$, o que pode ser considerado satisfatório para sementes de cafeeiro.

$\mathrm{O}$ uso da solução de pré-embebição com hipoclorito de sódio, com concentrações maiores de $6 \%$ de cloro ativo prejudicou as sementes, devido, provavelmente, a danos ocasionados aos tecidos do embrião ou regiões do tecido de reserva próximas a ele, reduzindo, consideravelmente, a percentagem de germinação. Por outro lado, observou-se que o tempo de pré-embebição de 3 horas, utilizando-se soluções de hipoclorito de sódio com concentrações inferiores a 5\% de cloro ativo, normalmente não foram suficientes para a completa degradação do pergaminho, proporcionando menor percentagem e índice de velocidade de germinação. Também verificou-se que no tempo de pré-embebição de 6 horas, o pergaminho foi degradado, eficientemente, exceto na concentração de $3 \%$ de cloro ativo. Entretanto, independentemente da concentração de hipoclorito de sódio ou do grau de umidade inicial das sementes, a pré-embebição durante um período de 6 horas, afetou negativamente a germinação das sementes, provavelmente devido à maior absorção de hipoclorito de sódio (Tabela 3), ocasionando danos aos tecidos de reserva da semente ou ao próprio embrião.

Os resultados obtidos na primeira contagem do teste de germinação (Tabela 5) apresentaram magnitude, entre os tratamentos, semelhante ao observado no teste de germinação, o que dispensa comentários.

O IVG também apresentou resultados semelhantes aos observados no teste de germinação e primeira contagem do teste de germinação (Tabela 6). Em sementes com grau de umidade de $23 \%$, a pré-embebição com hipoclorito de sódio durante 3 horas, com $6 \%$ de cloro ativo, foi o único tratamento que proporcionou velocidade de germinação das sementes semelhante à remoção manual do pergaminho. Quando as sementes apresentavam grau de umidade de 28\%, a utilização de hipoclorito de sódio nas concentrações de 4, 5 e $6 \%$ de cloro ativo, durante um período de 3 horas, promoveu IVG das sementes semelhante àquele causado pela remoção manual do pergaminho. Nas sementes que apresentavam grau de umidade de $33 \%$, a concentração de $6 \%$ de cloro ativo, durante 3 horas de pré-embebição, foi o único tratamento em que o IVG não diferiu daquele obtido com a remoção manual do pergaminho.

Concentrações de hipoclorito de sódio superiores a $6 \%$ de cloro ativo, provavelmente, ocasionaram sérias danificações aos tecidos das sementes, proporcionando redução na velocidade de germinação, mesmo quando se utilizou um período de pré-embebição de 3 horas. Por outro lado, concentrações inferiores a $6 \%$ de cloro ativo não degradaram, eficientemente, o pergaminho das sementes, exceto quando as sementes apresentavam grau de umidade de 28\%. Meireles (2004) utilizou sementes com grau de umidade de $28 \%$ e verificou que a pré-embebição em solução contendo hipoclorito de sódio, em concentrações de 7,5 e $10 \%$ de cloro ativo, danificou seriamente as estruturas vitais das sementes, enquanto que as concentrações inferiores a 5\% não degradaram eficientemente o pergaminho. 
TABELA 5. Primeira contagem do teste de germinação (\%) de sementes de cafeeiro, de acordo com o tratamento para degradação do pergaminho de sementes com diferentes graus de umidade inicial

\begin{tabular}{|c|c|c|c|c|c|c|}
\hline \multicolumn{2}{|c|}{ Tratamento } & \multicolumn{5}{|c|}{ Grau de umidade inicial das sementes (\% b.u.) } \\
\hline Cloro ativo $(\%)$ & Tempo (h) & 13 & 18 & 23 & 28 & 33 \\
\hline \multirow{2}{*}{3} & 3 & 26 & 10 & 5 & 28 & 4 \\
\hline & 6 & 11 & 47 & 60 & 62 & 59 \\
\hline \multirow{2}{*}{4} & 3 & 47 & 43 & 25 & $89^{*}$ & 29 \\
\hline & 6 & 6 & 50 & 59 & 15 & 66 \\
\hline \multirow{2}{*}{5} & 3 & 19 & 81 & 56 & $91^{*}$ & 72 \\
\hline & 6 & 0 & 30 & 32 & 7 & 35 \\
\hline \multirow{2}{*}{6} & 3 & 7 & 55 & $88^{*}$ & $94 *$ & $81^{*}$ \\
\hline & 6 & 0 & 21 & 11 & 0 & 17 \\
\hline \multirow{2}{*}{7} & 3 & 0 & 17 & 72 & 22 & 75 \\
\hline & 6 & 0 & 10 & 10 & 0 & 5 \\
\hline \multicolumn{2}{|c|}{$\begin{array}{l}\text { Sementes sem tratamento (com } \\
\text { pergaminho) }\end{array}$} & 1 & 11 & 19 & 17 & 9 \\
\hline \multicolumn{2}{|c|}{$\begin{array}{l}\text { Testemunha (sem pergaminho, remoção } \\
\text { manual) }\end{array}$} & 76 & 92 & 91 & 92 & 89 \\
\hline \multicolumn{2}{|l|}{ CV (\%) } & 24,2 & 11,8 & 11,1 & 7,6 & 10,3 \\
\hline
\end{tabular}

* Médias iguais ao tratamento testemunha pelo teste de Dunnett a 5\% de probabilidade, na mesma coluna.

TABELA 6. Índice de velocidade de germinação de sementes de cafeeiro, de acordo com o tratamento para degradação do pergaminho de sementes com diferentes graus de umidade inicial

\begin{tabular}{|c|c|c|c|c|c|c|}
\hline \multicolumn{2}{|c|}{ Tratamento } & \multicolumn{5}{|c|}{ Grau de umidade inicial das sementes (\% b.u.) } \\
\hline Cloro ativo $(\%)$ & Tempo (h) & 13 & 18 & 23 & 28 & 33 \\
\hline \multirow{2}{*}{3} & 3 & 2,63 & 1,42 & 0,62 & 2,88 & 0,69 \\
\hline & 6 & 0,87 & 4,43 & 5,61 & 5,40 & 5,21 \\
\hline \multirow{2}{*}{4} & 3 & 3,98 & 4,61 & 2,64 & $7,33^{*}$ & 3,48 \\
\hline & 6 & 0,46 & 4,14 & 4,97 & 1,22 & 5,46 \\
\hline \multirow{2}{*}{5} & 3 & 1,54 & 6,67 & 5,45 & $7,51 *$ & 6,52 \\
\hline & 6 & 0,00 & 2,46 & 2,63 & 0,56 & 2,88 \\
\hline \multirow{2}{*}{6} & 3 & 0,61 & 4,61 & $7,44^{*}$ & $7,74^{*}$ & $7,06^{*}$ \\
\hline & 6 & 0,00 & 1,71 & 0,88 & 0,00 & 1,39 \\
\hline \multirow{2}{*}{7} & 3 & 0,00 & 1,38 & 6,12 & 1,81 & 6,22 \\
\hline & 6 & 0,00 & 0,92 & 0,83 & 0,00 & 0,39 \\
\hline \multicolumn{2}{|c|}{$\begin{array}{l}\text { Sementes sem tratamento (com } \\
\text { pergaminho) }\end{array}$} & 0,07 & 1,21 & 1,61 & 1,83 & 0,85 \\
\hline \multicolumn{2}{|c|}{$\begin{array}{l}\text { Testemunha (sem pergaminho, remoção } \\
\text { manual) }\end{array}$} & 6,39 & 7,62 & 7,62 & 7,62 & 7,55 \\
\hline \multicolumn{2}{|l|}{ CV (\%) } & 21,6 & 9,8 & 8,9 & 7,7 & 9,7 \\
\hline
\end{tabular}

* Médias iguais ao tratamento testemunha pelo teste de Dunnett a $5 \%$ de probabilidade, na mesma coluna.

No teste de classificação do vigor de plântulas, as sementes com grau de umidade de $23 \%$, submetidas ao tratamento pré-germinativo com hipoclorito de sódio com concentração de $6 \%$ de cloro ativo, durante 3 horas, apresentaram percentagem de plântulas normais fortes semelhante ao tratamento testemunha (Tabela 7). Em sementes com grau de 
umidade de $28 \%$, os tratamentos com hipoclorito de sódio, nas concentrações de 5 e $6 \%$ de cloro ativo, durante 3 horas, também apresentaram percentagem de plântulas normais fortes semelhante à testemunha. Neste grau de umidade inicial das sementes, o tratamento pré-germinativo com hipoclorito de sódio, na concentração de 4\% de cloro ativo, apesar de ter proporcionado germinação e IVG (Tabelas 4 e 6) semelhantes à testemunha, resultou em menor percentagem de plântulas normais fortes (Tabela 7), em relação à remoção manual do pergaminho. Provavelmente, a degradação do pergaminho nesta concentração não tenha apresentado a mesma eficiência que as concentrações de 5 e $6 \%$ de cloro ativo, o que causou retardamento no crescimento das plântulas.

Em sementes com grau de umidade de $33 \%$, todos os tratamentos pré-germinativos promoveram percentual de plântulas fortes inferiores ao tratamento testemunha, com remoção manual do pergaminho (Tabela 7). Neste grau de umidade das sementes, a pré-embebição em hipoclorito de sódio na concentração de $6 \%$ de cloro ativo, durante 3 horas, foi eficiente tanto na degradação do pergaminho quanto no aumento da percentagem e velocidade de germinação (Tabelas 4 e 6); entretanto, o desempenho das plântulas foi inferior à remoção manual do pergaminho. Mesmo assim, para este grau de umidade, a pré-embebição das sementes em hipoclorito de sódio a $6 \%$, foi o tratamento pré-germinativo que apresentou maior percentagem de plântulas normais fortes.

De acordo com os resultados obtidos, o tratamento pré-germinativo com hipoclorito de sódio na concentração de $6 \%$ de cloro ativo, combinado com o tempo de exposição de 3 horas, é um método eficiente para degradação do pergaminho e aceleração da germinação de sementes de cafeeiro, com grau de umidade entre 23 e $33 \%$. Em sementes com grau de umidade inferior a $23 \%$, embora o hipoclorito de sódio, seja eficiente na degradação do pergaminho, provavelmente ocasione toxidez às sementes, nas concentrações e tempos de pré-embebição estudados. A toxidez ocasionada pelo hipoclorito de sódio nas sementes com grau de umidade inferior a $23 \%$, provavelmente, é decorrente da maior absorção de solução durante o período de pré-embebição. Novos estudos são necessários, no sentido de ajustar metodologias, que além de serem eficientes para degradação do pergaminho, não ocasionem efeitos prejudiciais ao desempenho germinativo das sementes com graus de umidade inferior a $23 \%$.

\section{CONCLUSÕES}

- A pré-embebição das sementes de cafeeiro em hipoclorito de sódio na concentração de $6 \%$ de cloro ativo, durante 3 horas, além de degradar o pergaminho

TABELA 7. Plântulas fortes (\%) de cafeeiro, de acordo com o tratamento para degradação do pergaminho de sementes com diferentes graus de umidade inicial

\begin{tabular}{|c|c|c|c|c|c|c|}
\hline \multicolumn{2}{|c|}{ Tratamento } & \multicolumn{5}{|c|}{ Grau de umidade inicial das sementes (\% b.u.) } \\
\hline Cloro ativo (\%) & Tempo (h) & 13 & 18 & 23 & 28 & 33 \\
\hline \multirow{2}{*}{3} & 3 & 2,63 & 1,42 & 0,62 & 2,88 & 0,69 \\
\hline & 6 & 0,87 & 4,43 & 5,61 & 5,40 & 5,21 \\
\hline \multirow{2}{*}{4} & 3 & 3,98 & 4,61 & 2,64 & $7,33^{*}$ & 3,48 \\
\hline & 6 & 0,46 & 4,14 & 4,97 & 1,22 & 5,46 \\
\hline \multirow{2}{*}{5} & 3 & 1,54 & 6,67 & 5,45 & $7,51^{*}$ & 6,52 \\
\hline & 6 & 0,00 & 2,46 & 2,63 & 0,56 & 2,88 \\
\hline \multirow{2}{*}{6} & 3 & 0,61 & 4,61 & $7,44 *$ & $7,74 *$ & $7,06^{*}$ \\
\hline & 6 & 0,00 & 1,71 & 0,88 & 0,00 & 1,39 \\
\hline \multirow[b]{2}{*}{7} & 3 & 0,00 & 1,38 & 6,12 & 1,81 & 6,22 \\
\hline & 6 & 0,00 & 0,92 & 0,83 & 0,00 & 0,39 \\
\hline \multicolumn{2}{|c|}{$\begin{array}{l}\text { Sementes sem tratamento (com } \\
\text { pergaminho) }\end{array}$} & 0,07 & 1,21 & 1,61 & 1,83 & 0,85 \\
\hline \multicolumn{2}{|c|}{$\begin{array}{l}\text { Testemunha (sem pergaminho, remoção } \\
\text { manual) }\end{array}$} & 6,39 & 7,62 & 7,62 & 7,62 & 7,55 \\
\hline \multicolumn{2}{|l|}{ CV (\%) } & 21,6 & 9,8 & 8,9 & 7,7 & 9,7 \\
\hline
\end{tabular}

* Médias iguais ao tratamento testemunha pelo teste de Dunnett a 5\% de probabilidade, na mesma coluna. 
eficientemente, proporciona germinação e índice de velocidade de germinação semelhantes ao tratamento testemunha (remoção manual do pergaminho), quando as sementes apresentam grau de umidade inicial entre 23 e $33 \%$;

- Nas sementes com grau de umidade de 13 e 18\%, a pré-embebição ocasiona maior absorção da solução contendo hipoclorito de sódio o que prejudica a germinação

\section{AGRADECIMENTOS}

Os autores agradecem ao Conselho Nacional de Desenvolvimento Científico e Tecnológico ( $\mathrm{CNPq}$ ) pelo apoio financeiro.

\section{REFERÊNCIAS}

ARAUJO, E.F.; REIS, L.S.; MEIRELES, R.C.; SERRANO, L.A.L. Efeito da danificação mecânica e da remoção manual do pergaminho sobre a emergência das plântulas de Coffea arabica L. Revista Brasileira de Armazenamento, Viçosa, v. Especial Café, n.8, p. 1-5, 2004.

ARAUJO, R.F. Influência do teor de umidade, da embalagem e do ambiente de armazenamento na conservação de sementes de café (Coffea arabica L.). 1988. 56 f. Dissertação (Mestrado em Fitotecnia) - Departamento de Fitotecnia, Universidade Federal de Viçosa, Viçosa.

BACCHI, O. Estudo sobre conservação de sementes: IV. Café. Bragantia, Campinas, v.17, n.20, p. 261-270, 1958.

BACCHI, O. Novos ensaios sobre a seca das sementes de café ao sol. Bragantia, Campinas, v.15, n.8, p. 83-91, 1956.

BACCHI, O. Seca da semente de café ao sol. Bragantia, Campinas, v.14, n.22, p. 225-236, 1955.

BRASIL. Ministério da Agricultura e Reforma Agrária. Regras para análise de sementes. Brasília: SNAD/DNDV/ CLAV, 1992. 365p.

CARVALHO, G.R.; PASQUAL, M.; GUIMARÃES, R.J.; MENDES, A.N.G.; BEARZOTI, E.; FALCO, L. Efeito do tratamento de sementes na emergência e desenvolvimento de mudas de cafeeiro Coffea arabica L. Ciência e Agrotecnologia, Lavras, v.23, n.4, p. 799-807, 1999.

DENCE, C.W. Chemistry of chemical pulp bleaching. In: DENCE, C.W.; REEVE, D.W. Pulp bleaching - principles and practice. Atlanta, Georgia-USA: Tappi Press, 1996. Seção III, cap. 3, p. 125-159.
ELÍAS, L.G. Composición química de la pulpa de café y otros subproductos. In: BRAHAM, J.E.; BRESSANI, R. Pulpa de Café - Composición, tecnologia y utilización. Bogotá, Colombia: Instituto de Nutrición de Centro América y Panamá, 1978. cap. 2, p. 19-29.

ELLIS, R.H.; HONG, T.D.; ROBERTS, E.H. An intermediate category of seed storage behaviour? I. Coffee. Journal of Experimental Botany, Oxford, v.41, n.230, p. 1167-1174, 1990.

GENTIL, D.F.D.O. Conservação de sementes do cafeeiro: resultados discordantes ou complementares. Bragantia, Campinas, v.60, n.3, p. 149-154, 2001.

GUIMARÃES, J.R.; FRAGA, A.C.; MENDES, A.N.G.; CARVALHO, M.L.M.D.; PASQUAL, M.; CARVALHO, G.R. Efeitos da citocinina, giberelina e remoção do endocarpo na germinação de sementes de cafeeiro (Coffea arabica L.). Ciência e Agrotecnologia, Lavras, v.22, n.3, p. 390-396, 1998.

HISE, R. Chlorination. In: DENCE, C.W.; REEVE, D.W. Pulp bleaching - principles and practice. Atlanta, Georgia-USA: Tappi Press, 1996. Seção IV, cap. 2, p. 241-259.

MAGUIRRE, J. D. Speed of germination-aid in selection and evaluation for seedling emergence and vigour. Crop Science, Madison, v.2, n.2, p. 176-177, 1962.

MEIRELES, R.C. Efeito do hipoclorito de sódio e da embebição em água na germinação das sementes de café (Coffea arabica L.). 2004. 56 f. Dissertação (Mestrado em Fitotecnia). Departamento de Fitotecnia, Universidade Federal de Viçosa, Viçosa.

RENA, A.B.; MAESTRI, M. Fisiologia do cafeeiro. In: RENA, A. B.; MALAVOLTA, E.; ROCHA, M.; YAMADA, T. Cultura do cafeeiro; fatores que afetam a produtividade. Piracicaba: POTAFÓS, 1986. p. 13-85.

ROBERTS, E.H. Predicting the storage life of seeds. Seed Science and Technology, Zürich, v.1, p. 449-514, 1973.

SGUAREZI, C.N.; BRACCINI, A.L.; SCAPIM, C.A.; BRACCINI, M.C.L.; DALPASQUALE, V.A. Avaliação de tratamentos pré-germinativos para melhorar o desempenho de sementes de café (Coffea arabica L.). II. Processo de umidificação. Revista Brasileira de Sementes, Londrina, v.23, n.2, p. 162-170, 2001.

SILVA,E.A.A;TOOROP,P.E;AELST,A.C.V.;HILHORST, H.W.M. ABA regulates embryo growth potential and endosperm cap weakening during coffee (Coffea arabica cv. Rubi) seed germination. Planta, Alemanha, v. 220, n. 2, p. 251-261, 2004. 
SILVA, W.R.; DIAS, M.C.L.D.L. Interferência do teor de umidade das sementes de café na manutenção de sua qualidade fisiológica. Pesquisa Agropecuária Brasileira, Brasília, v.20, n.5, p. 551-560, 1985.

VALIO, I.F.M. Germination of coffee seeds (Coffea arabica
L. cv. Mundo Novo). Journal of Experimental Botany, v.27, n.100, p. 983-991, 1976.

VALIO, I.F.M. Inhibition of germination of coffee seeds (Coffea arabica L.) cv. Mundo Novo by the endocarp. Journal of Seed Technology, East Lansing, v.5, n.1, p. 32-39, 1980. 